\title{
Adam Mickiewicz Institute
}

The Adam Mickiewicz Institute is a national cultural institute with a mission to build and communicate the cultural dimension of the Poland brand through active participation in international cultural exchange. All of the Institute's projects carry our flagship brand, Culture.pl.

The Institute's Culture.pl portal offers a daily information service covering key events related to Polish culture around the world. In addition to information on events organised in Poland and abroad, the portal features numerous artist profiles, reviews, essays, descriptive articles, and information about cultural institutions. The site is available in three languages: Polish, English and Russian.

Recently, Culture.pl announced a new project: Stories From The Eastern West. It is a new audio show that reveals the hidden history of Central and Eastern Europe. Intertwining in-depth interviews, rich sound design, and original music to build compelling narrative stories, the podcast is the start of a new chapter for Culture.pl.

For more information go to Culture.pl.

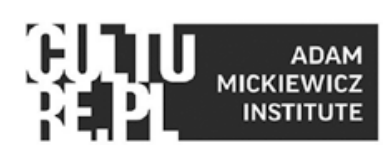


This page intentionally left blank 